\title{
ASPECTS REGARDING THE DESIGN, PRACTICAL REALIZATION AND IMPLEMENTATION OF A FUNCTIONAL PROTOTYPE OF WHEELED MINIROBOT FOR ENGINEERING RECONNAISSANCE
}

\author{
Antonia-Renata COROIU, Silviu-Mihai PETRIȘOR \\ "Nicolae Bălcescu" Land Forces Academy, Sibiu, Romania \\ acoroiu67@gmail.com, robmilcap@gmail.com
}

\begin{abstract}
For this scientific paper, a study was carried out on communication railways in order to identify potential threats that could hinder the achievement of the objectives of a national or international mission and the modalities to counter the respective threats by using a remote-controlled robotic technological product or operating in autonomous mode [1]. The paper is divided into four chapters. The first chapter presents the engineering reconnaissance syntagm, its importance in the military field and the importance of implementing robotic technologies in such actions. In the second chapter deals with the actual making of the prototype, taking into account the established hypotheses and operational objectives. The third chapter describes the real field simulation of the designed and constructed prototype to confirm its usefulness on the battlefield and to convince as many military structures as possible to implement/integrate it with the troops and the fourth chapter describes the conclusions and proposal.
\end{abstract}

Keywords: robotic technological product, human-artificial partnership, technological humanism, avant-garde element of the human factor

\section{Brief introduction - engineering reconnaissance using robotic technologies}

The present paper aims at highlighting the importance of implementing robotic technological products in the military field. The revolution of the military technologies has led to a change in strategic thinking, people considering, nowadays, that the robotization of the combat environment is necessary for the missions of the armies of all the states to proceed at normal parameters. The main aspect that the modern robotic military technologies aim at is the prompt response to battlefield threats, the quick and efficient reaction to attacks on critical infrastructure [2]. The use of these technologies to obtain the necessary information on threats to critical structures on time is an advantage of the armed forces, because potential threats could be avoided or eliminated with the help of robots. The need to use advanced technological systems is essential for the protection and the safety of military personnel, because they, in addition to carrying out monotonous missions involving maximum physical and mental concentration, are subjected to highrisk missions in which much of their physical and moral integrity is affected. The risks to which the military are often exposed can be diminished by using special equipment systems with a role in investigating and identifying the enemy and the barriers considered to be detrimental to the fulfillment of military actions in international missions or aimed at national defense [3].

Engineering recconnaissance is a basic activity in combined arms missions; it is 
intended to procure critical information from the conflict areas and to give early warning to units and large units concerning possible dangers in the area under investigation. The purpose of engineering reconnaissance is to provide a comprehensive report on the degree of acceptability of travel itineraries. The engineering reconnaissance carried out by the human factor is not exactly an easy job. This involves, in addition to the demanding work, specialized personnel capable to obtain and transmit, in very short time, the necessary information to the commander on the state of the objectives in order to ensure the mobility of his own forces and the support of combat operations. There are cases when the information does not reach the decision-making structure in time due to technical defects, such as jamming, which prevents the use of radio stations, or difficulties encountered in the area where the reconnaissance activity is carried out, which make it difficult for the engineering troops to obtain concrete information on the established objective. In order to avoid all these errors, the integrated battlefield of the future requires the use of modern robotic technologies by means of which the safety of the human factor increases as it ceases to be the main target in the context of military interventions. The implementation in the military field of such technologies contributes to obtaining real-time technical information that may or may not provide the freedom of movement of the friendly forces.

\section{Conception and practical realization of the robotic technological product R-Recbot}

R-Recbot (Rail Reconnaissance Robot) represents a technological product that tends towards autonomy for the genius research of the whole set of railways (infrastructure, superstructure, works of art, etc.). The prototype of this robot was made to highlight and explain in detail the main features and operation of the robot itself. It will research the railways both during the day and at night, by manual control by an operator, using the keys of a laptop or by autonomous programming, offering in both variants the possibility of operating the robot within a radius of $3 \mathrm{~km}$.

The first step in order to make the prototype is to establish the electronic components necessary for the specific operation of the research: Raspberry Pi development board, L298N motor driver module, Pi NoIR V2 camcorder, 3 HC-SR04 ultrasonic sensors, 4 DC motors with reducer, 2 servomotors SG90, a breadboard, a $9 \mathrm{~V}$ battery, an external Asus $10050 \mathrm{mAh}$ battery. After establishing the electronic components, the diagram of the electrical circuit was made, according to Figure 1, which was the basis for the construction of the electronic part of the R-Recbot robot and implicitly of its prototype.

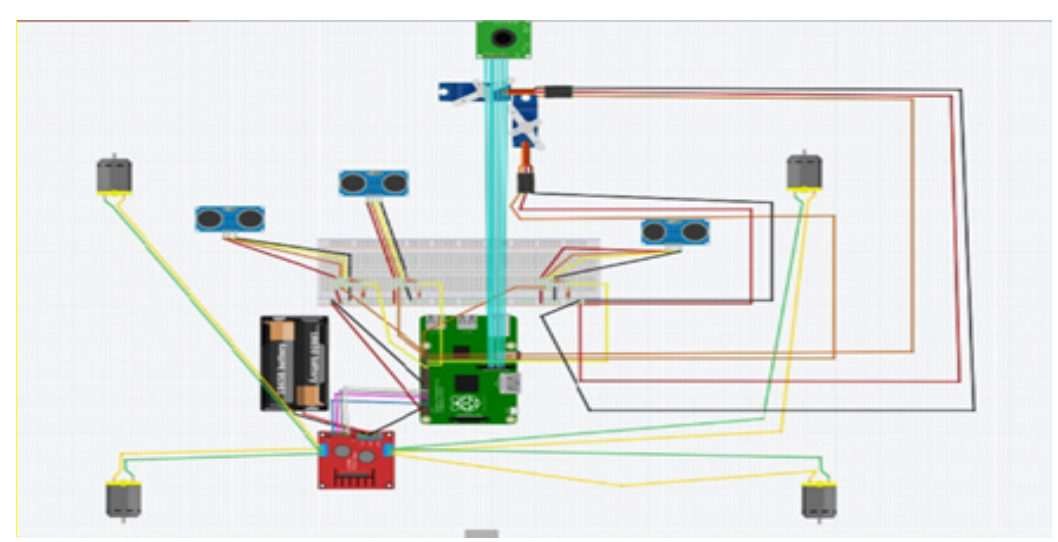

Figure 1: Diagram of the electrical circuit of the R-Recbot robot 
Once the electronic part of the R-Recbot prototype was made, its chassis and body and a rail model were built to simulate railway research. The process of making the robot consisted in designing a graphic scheme, according to Figure 2, which helped to assemble the parts and to achieve the actual design of the prototype.

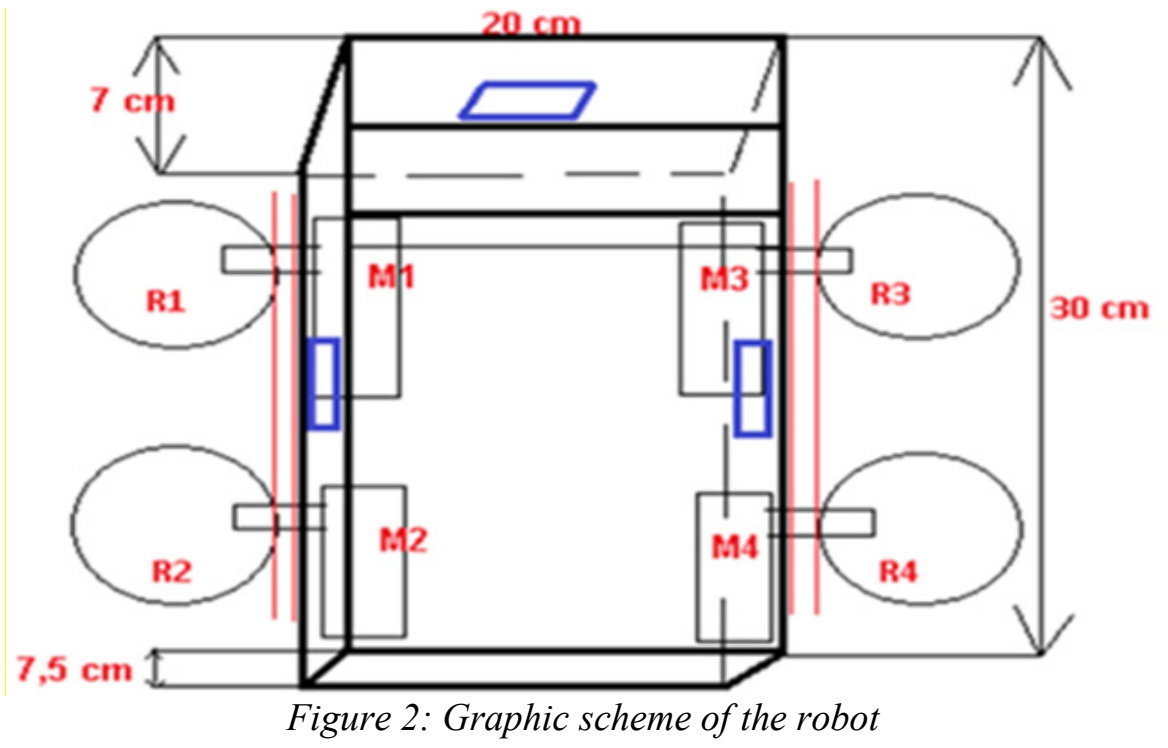

Light materials (galvanized sheet, fiberglass platforms), but resistant ones, were used for the construction of such a prototype, materials that can not be affected by possible strong shocks, thus providing the safety of mounting the other parts of the robot. In order to be able to later demonstrate the operation of the robotic technological product R-Recbot, a model of the railway was made, using aluminum materials to mark the physical resistance of a real railway.
The robot, presented in Figure 3 (front view) and 4 (side view), works thanks to the Raspberry Pi development board with which the instructions are transmitted to its other electronic components. The instructions are encrypted in a programming code written in a specific programming language, namely the Python language.

At the same time, the robot has two ways of operation: remotely controlled by an operator or autonomy, for which we used different programming codes

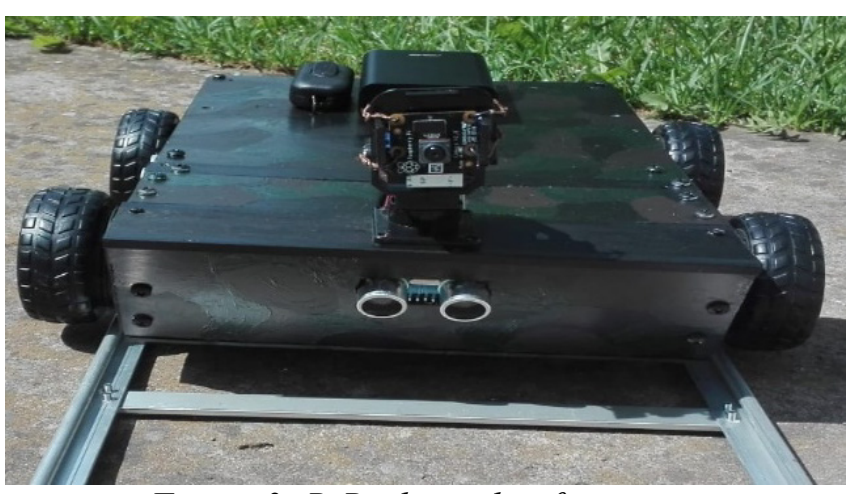

Figure 3: R-Recbot robot front view 


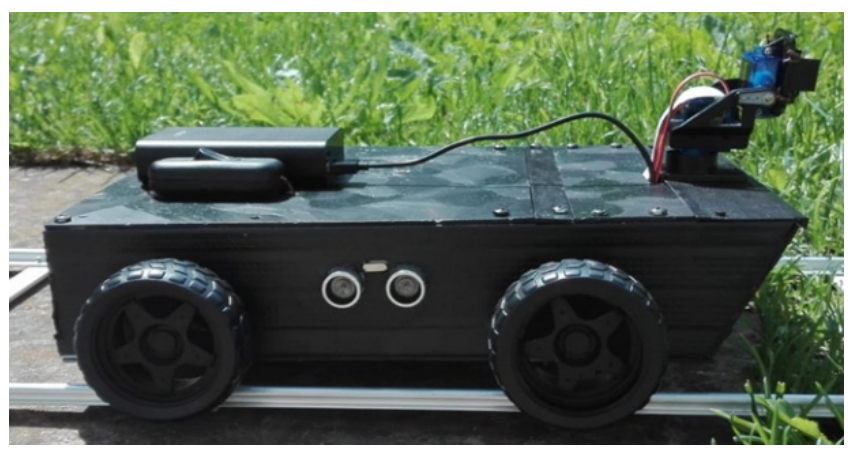

Figure 4: R-Recbot robot side view

\section{Real field implementation and simulation of the technological product}

The purpose of this practical work is to create a remote-controlled mini-robot on wheels that is programmed to carry out research missions of communication routes, especially railways, in the field of engineering structures [4].

The remote-controlled robot will be used to ensure the mobility of troops in various demanding missions, with a high degree of risk, by conducting research on railways that are a means of transporting human resources, but also technical systems that include heavy non-transportable weapons.

If the robot is subjected to research, it will be sent for reconnaissance before the research group acts, in order to perform its duties in order to obtain the necessary data that will be used by the commander in the decision-making process, in the planning. Actions and their optimal execution and last but not least, in the continuity of management. By using this mini-robot on wheels, the genius research troops not only make their work easier, but also maintain their own safety and reduce the dangers that can endanger their lives or their own forces of other specializations. This prototype effectively contributes to the optimization of engineering research missions, offering the possibility to eliminate the risks and threats to which both the military and civilian personnel are exposed. R-Recbot will contribute to the replacement of engineering research teams and implicitly to their protection against potential enemies or possible obstacles, being able to collect and transmit the necessary information in real time to the operator who will control it using wireless software.

Starting from the idea of developing the robotic battlefield, it was decided to design the R-Recbot prototype, choosing as a method of evaluating it the modeling and simulation. In order to be able to implement this method it was necessary to establish a model and simulate the result in the real field to validate the hypotheses. The model chosen is the R-Recbot itself, which is a system because the interdependent components make it a whole capable of responding to the missions for which it was designed. In order to study its implications on military actions, it was necessary to run the model in a certain situation (simulation). Therefore, the designed model must be remotely controlled and reliable in order to make possible the massive integration of troops specialized in the field in which it operates. In order to simulate the functionality of the model in real field, the model of the railway was used to mark an action that genius research of the respective ensemble. This simulation process helped to establish exactly its main technicaltactical characteristics. Both the constructive and the technical-tactical characteristics demonstrated that the model can be used in all three operational areas, namely tactical, operational and strategic.

In order to establish the efficiency of the prototype designed and made in the laboratory in order to implement/ integrate it within the structures that carry out missions to identify and transmit genetic information on obstacles-threats that may be located on railway roads in the area of 
responsibility, a cost-effectiveness analysis [5]. In order to carry out this analysis, in addition to the model created, the three robots presented in the current state at national and international level were taken into account and the characteristics of each were centralized. By performing the costeffectiveness analysis we want to demonstrate that the robot designed in the laboratory is the most suitable in terms of efficiency and cost of design and acquisition. In order to establish the costeffectiveness ratio, according to Table 1, the life cycle was calculated based on the costs of development, realization, support or operation and scrapping. According to the table, the best robot variant that can be integrated into military subunits is the RRecbot, because it has the lowest value of cost-effectiveness.

Table 1 Cost-effectiveness analysis

\begin{tabular}{|c|r|r|r|r|r|r|}
\hline \multicolumn{2}{|c|}{ COST (lei) } \\
\hline Versions & $\begin{array}{c}\text { COST } \\
\text { DEVELOP- } \\
\text { MENT }\end{array}$ & $\begin{array}{c}\text { COST } \\
\text { BUILT }\end{array}$ & $\begin{array}{r}\text { COST } \\
\text { SUPPORT }\end{array}$ & $\begin{array}{r}\text { SCRAP- } \\
\text { PING }\end{array}$ & LCC & $\begin{array}{r}\text { Cost- } \\
\text { effective- } \\
\text { ness }\end{array}$ \\
\hline $\begin{array}{c}\text { Nerva } \\
\text { LG [6] }\end{array}$ & 73500 & 950000 & 7000 & 1000 & 109450 & 1275600,0 \\
& & & & & & 6 \\
\hline $\begin{array}{c}\text { Throw- } \\
\text { bot 2 [7] }\end{array}$ & 55000 & 80000 & 3250 & 850 & 168350 & 367411,86 \\
\hline $\begin{array}{c}\text { Wheeled } \\
\text { Mini- } \\
\text { robot [2] }\end{array}$ & 17800 & 35000 & 2000 & 250 & 73050 & 387085,60 \\
\hline $\begin{array}{c}\text { R- } \\
\text { Recbot }\end{array}$ & 400 & 750 & 250 & 150 & 3800 & 9919,81 \\
\hline
\end{tabular}

\section{Conclusions and proposals}

The main pillar for the design and implementation of the R-Recbot project was the knowledge of the current state at national and international level of the most advanced robotic technologies for reconnaissance missions. The research has generated information on the limits of robotic products and for which their designers are trying to find ways to eliminate them.

The use of robots in reconnaissance missions, in addition to bringing a great deal of safety and security to the human factor, also succeeds in streamlining actions on the battlefield. However, the specialized human resource is not fully replaced; it has the role of remotely coordinating the actions of the robot to successfully accomplish the objectives of the mission.

The concept of the R-Recbot robot satisfies certain limitations of the existing construction models on the national and international market by the fact that the budget allocated for realization and integration is reduced compared to the other robots on the international market. The most important aspect is that this prototype is one of the few robotic products that researches railways and identifies obstacles or barriers that could endanger human life and make it difficult to carry out military actions.

\section{References List}

[1] Coroiu Antonia, Design and practical realization of a wheeled minirobot intended for motorering reconnaissance. Study on railways, The International Student Innovation and Scientific Reconnaissance Exhibition - "Cadet INOVA'20" pp. 238-242, Sibiu, România, 2020. 
[2] Petrișor, S.M., Popa Petrișor, R., Mecatronica- intre imperativele contemporane și paradigma umanisto-tehnologică, Sibiu, Editura Academiei Forțelor Terestre „Nicolae Bălcescu", 2014.

[3] Doare, R., Danet, D., Hanon, J., Boisboisel, G., Robots on the battlefield. Contemporary perspectives and implication for the future, Kansas, Editura Combat Studies Institute Pres US Army Combined Arms Center Fort Leavenwork, 2014.

[4] Epure, I.,Inteligența artificială din câmpul de luptă integrat, București, Editura Militară, 2014.

[5] Bârsan, G., Badea, D., Coman, M., Stanic, M., Modelarea și simularea activităților și acțiunilor militare, Sibiu, Editura Academiei Forțelor Terestre „Nicolae Bălcescu”.

[6] https://solidrobotics.com/en/robots-2/nerva-lg/, accessed on 02.03.2021.

[7] https://reconrobotics.com/products/throwbot-2-robot/, accessed on 02.03.2021.

\section{Supplementary bibliography}

Giurgiu Luminiţa, Bârsan Ghiţă, Moşteanu Dănuţ, The technical dimension of knowledge management in the context of learning and training, The 9th International Management Conference "Management and Innovation For Competitive Advantage", November 5th-6th, 2015, Bucharest, Romania. 